\title{
UJI ANTI BAKTERI EKSTRAK DAUN BELIMBING WULUH (Averrhoa bilimbi L) TERHADAP ZONA HAMBAT BAKTERI JERAWAT Propionibacterium acnes SECARA IN VITRO
}

\author{
Ruhana Afifi ${ }^{1)}$, Euis Erlin ${ }^{2)}$, Jeti Rachmawati ${ }^{3)}$ \\ ${ }^{123}$ Dosen Pendidikan Biologi FKIP Universitas Galuh-Ciamis \\ E-mail: ruhanaafifi@yahoo.com
}

APA Citation: Afifi, R. Erlin, E., \& Rachmawati, J. (2018). Uji Anti Bakteri Ekstrak Daun Belimbing Wuluh (Averrhoa bilimbi L) Terhadap Zona Hambat Bakteri Jerawat Propionibacterium cnes Secara In Vitro. Quagga: Jurnal Pendidikan dan Biologi, 10(1), 10-17. doi: 10.25134/quagga.v10i1.803.

\begin{abstract}
Abstrak: Jerawat (acne vulgaris) merupakan penyakit kulit yang terjadi karena adanya penyumbatan folikel oleh sel-sel mati, sebum, dan peradangan yang disebabkan oleh bakteri Propionibacterium acnes pada folikel sebasea. Antibiotik dapat mengobati jerawat namun dapat menimbulkan resistensi dari suatu bakteri, sehingga diperlukan cara yang lebih aman dan lebih murah. Salah satunya dengan penggunaan daun Belimbing wuluh (Averrhoa bilimbi L) karena mengandung zat aktif Flavonoid dan Tanin yang berfungsi sebagai antibakteri. Penelitian ini bertujuan untuk mengetahui pengaruh perbedaan konsentrasi ekstrak daun belimbing wuluh terhadap zona hambat bakteri P. acnes secara invitro dan mengetahui konsentrasi minimal ekstrak yang dapat menghambat pertumbuhan bakteri $P$. acnes. Penelitian ini bertempat di Laboratorium Biologi FKIP Universitas Galuh, dilakukan dengan menggunakan metode eksperimen dan didesain menggunakan Rancangan Acak Lengkap (RAL). Teknik pengujian menggunakan metode sumur dengan tujuh perlakuan dan empat kali ulangan. Konsentrasi ekstrak daun belimbing wuluh yang digunakan berdasarkan hasil penelitian pendahuluan adalah 75 $\mathrm{mgml}^{-1}, 100 \mathrm{mgml}^{-1}, 125 \mathrm{mgml}^{-1}, 150 \mathrm{mgml}^{-1}, 175 \mathrm{mgml}^{-1}, 200 \mathrm{mgml}^{-1}$, dan $225 \mathrm{mgml}^{-1}$. Parameter yang digunakan adalah dengan mengukur diameter zona hambat pada daerah bening sekitar sumur yaitu daerah yang tidak ditumbuhi bakteri dalam satuan milimeter. Data yang diperoleh dianalisis dengan Analisis Varian Satu Faktor (ANAVA), dan berdasarkan hasil analisis diperoleh $F_{\text {hitung }} 285,28$ lebih besar dari $F_{\text {tabel }}(0,01)$ dengan taraf nyata $(\alpha)$ 1\% sebesar 3,81 yang berarti bahwa perbedaan konsentrasi ekstrak daun belimbing wuluh berpengaruh sangat nyata terhadap diameter zona hambat pertumbuhan bakteri P. acnes yang terbentuk secara in-vitro. Berdasarkan hasil Uji Jarak Berganda Duncan diperoleh bahwa konsentrasi minimal ekstrak daun Belimbing wuluh yang dapat menghambat pertumbuhan bakteri bakteri P. acnes secara in-vitro adalah $100 \mathrm{mgml}^{-1}$.
\end{abstract}

Kata kunci: Anti bakteri, Ekstrak daun belimbing wuluh, Propionibacterium acnes, In vitro

\begin{abstract}
Acne (acne vulgaris) is a skin disease that occurs due to follicle blockage by dead cells, sebum, and inflammation caused by the bacteria Propionibacterium acnes in sebaceous follicles. Antibiotics can treat acne but can cause resistance from a bacterium, so a safer and cheaper method is needed. One of them is the use of leaves of starfruit (Averrhoa bilimbi L) because it contains the active ingredient Flavonoids and Tanin which function as antibacterial. This study aims to determine the effect of differences in concentrations of starfruit leaf extract to the inhibition zone of P. acnes bacteria in-vitro and determine the minimum concentration of extracts that can inhibit the growth of $P$. acnes bacteria. This study took place at the Biology Laboratory FKIP Galuh University, conducted using an experimental method and was designed using a Completely Randomized Design (CRD). The testing technique uses the well method with seven treatments and four replications. The concentration of the starfruit leaf extract used based on the results of the preliminary study was $75 \mathrm{mgml}-1,100 \mathrm{mgml}-1,125$ mgml-1, $150 \mathrm{mgml}-1,175 \mathrm{mgml}-1,200 \mathrm{mgml}-1$, and $225 \mathrm{mgml}-1$. The parameters used are by measuring the diameter of the inhibitory zone in the clear area around the well, which is an area that is not overgrown with bacteria in millimeters. The data obtained were analyzed by One Factor Variant Analysis (ANAVA), and based on the results of the analysis obtained Fcount 285.28 was greater than Ftable (0.01) with a significance level ( $\alpha$ ) of $1 \%$ of 3.81 which means that the difference in leaf extract concentration Wuluh starfruit has a very significant effect on the diameter of the inhibition zone of the growth of P. acnes bacteria formed in vitro. Based on the results of Duncan's Multiple Distance Test, it
\end{abstract}


was found that the minimum concentration of starfruit leaf extract which could inhibit the growth of invitro P. acnes bacterial bacteria was $100 \mathrm{mgml}-1$.

Keywords: Anti-bacterial, Wuluh starfruit leaf extract, Propionibacterium acnes, In vitro

\section{PENDAHULUAN}

Obat asli Indonesia sudah dikenal sejak dulu, jauh sebelum pelayanan kesehatan formal dengan obat-obat modern yang digunakan sekarang oleh masyarakat secara luas. Salah satu obat asli Indonesia yang sudah digunakan oleh masyarakat sejak dulu adalah daun belimbing wuluh (Averrhoa bilimbi L).

Masyarakat menggunakan daun belimbing wuluh ini antara lain untuk mengurangi rasa sakit atau nyeri, menurunkan kadar gula darah, bunganya juga dapat digunakan sebagai obat batuk dan perasan air buah sangat baik untuk asupan vitamin $\mathrm{C}$ dan di samping itu perasan buah juga dapat dipakai untuk keramas sebagai penghilang ketombe, atau digosokkan sebagai penghilang panu (Arland, 2006). Berkenaan dengan penggunaan daun belimbing wuluh tersebut, maka daun belimbing wuluh dapat berperan sebagai antibiotik alami.

Alasan penggunaan daun belimbing wuluh sebagai antibiotik alami ini karena daun belimbing wuluh (A. bilimbi $L)$ mengandung zat-zat aktif yang berperan sebagai zat anti bakteri. Senyawa-senyawa kimia tersebut diantaranya adalah Tanin, Flavonoid, Glukosida, Asam Formiat, Asam Sitrat, dan beberapa mineral (terutama Kalsium dan Kalium). Salah satu fungsi dari Flavonoid dan Tanin adalah kerjanya sebagai antibakteri. Zat-zat tersebut merupakan senyawa aktif dalam tanaman yang berkhasiat sebagai obat yang dapat menyembuhkan penyakit infeksi yang disebabkan oleh bakteri (Kamilah, 2010; Robinson,1995; Fahrani ,2009).

Mengingat keberadaan kandungan zat antibakteri pada daun belimbing wuluh tersebut, maka daun belimbing wuluh dianggap tepat untuk mencegah atau mengobati infeksi kulit.

Salah satu infeksi kulit yang hampir setiap orang pernah mengalaminya adalah penyakit jerawat (acne vulgaris). Penyakit ini menyerang pilosebasea kulit yaitu bagian kelenjar sebasea dan folikel rambut. Menurut Brown (2009) bahwa pembentukan jerawat terjadi karena adanya penyumbatan folikel oleh sel-sel mati, sebum, dan peradangan yang disebabkan oleh bakteri Propionibacterium acnes (P. acnes) pada folikel sebasea. Bentuk jerawat seperti bisul berisi dan kadang-kadang menjadi keras. Pada kulit terutama wajah terdapat benjolanbenjolan kecil, berkepala kuning, berisi nanah, terasa gatal dan sedikit nyeri.

$P$. acnes berperan pada patogenesis jerawat dengan menghasilkan lipase yang memecah asam lemak bebas dari lipid kulit. Asam lemak ini dapat mengakibatkan inflamasi jaringan ketika berhubungan dengan sistem imun dan mendukung terjadinya jerawat. $P$. acnes termasuk bakteri yang tumbuh relatif lambat. Genome dari bakteri ini telah dirangkai dan sebuah penelitian menunjukkan beberapa gen yang dapat menghasilkan enzim untuk meluruhkan kulit dan protein, yang immunogenic (Azrifitria, 2010).

Mekanisme terjadinya jerawat adalah bakteri $P$. acnes merusak stratum korneum dan stratum germinativum dengan cara menyekresikan bahan kimia yang menghancurkan dinding pori. Kondisi ini dapat menyebabkan inflamasi. Asam lemak dan minyak kulit tersumbat dan mengeras. Jika jerawat disentuh maka inflamasiakan meluas sehingga padatan asam lemak dan minyak kulit yang mengeras akan membesar (Alhidayati, 2007).

Pengobatan jerawat dilakukan dengan cara memperbaiki abnormalitas folikel, menurunkan produksi sebum, menurunkan jumlah koloni P.acnes, dan menurunkan inflamasi pada kulit. Populasi bakteri $P$ acnes dapat diturunkan dengan memberikan antibiotik seperti eritromisin, klindamisin, dan benzoil peroksida. Menurut Azrifitria (2010), meskipun penggunaan antibiotik cukup efektif mengatasi jerawat, namun penggunaan antibiotik sebagai pilihan utama penyembuhan jerawat harus ditinjau kembali untuk membatasi perkembangan resistensi bakteri terhadap antibiotik.

Hal tersebut mendorong penemuan sumber obat-obatan antibakteri lain dari 
Quagga: Jurnal Pendidikan dan Biologi Volume 10, Nomor 1, Januari 2018

bahan alam, yang dapat berperan sebagai antibakteri yang lebih aman dan relatif lebih murah. Untuk memperoleh bukti ilmiah penggunaan daun belimbing wuluh sebagai antibiotik alami pada pengobatan jerawat, maka perlu dilakukan pengujian berbagai konsentrasi ekstrak daun belimbing wuluh terhadap pertumbuhan bakteri $P$ acnes. Pertumbuhan bakteri bisa diamati dengan menentukan ukuran zona hambat bakteri.

Flavonoid dalam ekstrak belimbing wuluh pada konsentrasi rendah dapat merusak membran sitoplasma yang menyebabkan bocornya metabolit penting yang menginaktifkan sistem enzim bakteri, sedangkan pada konsentrasi tinggi mampu merusak membran sitoplasma dan mengendapkan protein sel (Robinson,1995)

Menurut Gilman (Kamilah, 2010) ada perusakan membran sel, ion $\mathrm{H}^{+}$dari senyawa fenol dan turunannya (flavonoid) akan menyerang gugus polar (gugus fosfat) sehingga molekul fosfolipid akan terurai menjadi gliserol, asam karboksilat, dan asam fosfat. Hal ini mengakibatkan fosfolipid tidak mampu mempertahankan bentuk membran sel, akibatnya membran akan bocor dan bakteri mengalami hambatan pertumbuhan bahkan kematian.

Fenol dan polifenol bersifat toksik terhadap mikroorganisme, hidroksilasi yang meningkat menyebabkan toksisitas yang meningkat pula. Mekanisme yang dianggap bertanggung jawab terhadap toksisitas fenolik pada mikroorganisme adalah bahwa fenol berperan sebagai inhibitor enzim, merusak membran sitoplasma yang menyebabkan bocornya metabolit penting, mengadakan interaksi non-spesifik dengan protein dan secara total dapat mengendapkan protein sel (Volk and Wheeler, 1988; Sarastani dkk, 2002).

Menurut Fahrani (2009) pelarut etanol : air (7:3) adalah pelarut yang terbaik untuk memperoleh ekstrak senyawa tanin. Senyawa tanin mampu menghambat pertumbuhan mikroorganisme dengan kemampuanya menginaktivasi adhesin mikroba, enzim dan protein transpor cell envelove. Tanin ini juga digunakan sebagai astringent baik untuk saluran pencernaan maupun kulit dan juga dapat digunakan sebagai obat diare.
p-ISSN 1907-3089, e-ISSN 2651-5869

https://journal.uniku.ac.id/index.php/quagga

Banyak faktor yang dapat mempengaruhi efektifitas zat anti mikroba, diantaranya adalah waktu kontak, populasi jenis mikroba yang akan dibinasakan, temperatur, $\mathrm{pH}$, jenis material yang ada pada jasad renik dan konsentrasi zat antimikroba itu sendiri (Jawetz, Melnick \& Adelberg, 1996; dan Cappucino,1982).

Konsentrasi zat anti mikroba mempenganuhi pertumbuhan mikroorganisme, artinya jika konsentrasi zat antimikroba pada ekstrak daun belimbing wuluh berbeda maka pertumbuhan mikroba pun akan berbeda, dimana konsentrasi yang lebih besar akan menyebabkan jumlah kematian yang lebih besar pula terhadap mikroba. Pada akhirnya konsentrasi berbeda akan memperlihatkan zona hambat berbeda pada masing-masing pertumbuhan mikroba.

Berdasarkan aturan dalam penentuan dosis obat kedokteran, sebelum dilakukan uji in-vivo terlebih dahulu diperlukan Konsentrasi Hambat Minimum (KHM) atau Minimal Inhibitor Concentration (MIC) dari zat antimikroba melalui pengujian in-vitro. Hal ini dianggap lebih efektif digunakan karena penggunaan zat antimikroba dalam konsentrasi yang tinggi dikhawatirkan akan menimbulkan efek samping atau efek fisioligis bagi tubuh (Jawetz, Melnick \& Adelberg, 1996).

Hasil penelitian Zakaria et.al. (Kamilah, 2010) daun belimbing wuluh mempunyai aktivitas antibakteri terhadap bakteri Gram positif seperti $S$. aureus, S. epidermidis, $C$. diphteriae, B. cereus, dan $K$. rhizophilla dengan konsentrasi sebesar $100 \mathrm{mg} \mathrm{ml}^{-1}$. Sedangkan menurut Kamilah (2010) hasil uji aktifitas antibakteri daun belimbing wuluh dengan pelarut aseton : air (7:3) terhadap bakteri $S$. aureus dan Escherichia coli menunjukkan bahwa pada konsentrasi $50 \mathrm{mg}$ $\mathrm{ml}^{-1}$ sampai $400 \mathrm{mg} \mathrm{ml}^{-1}$ senyawa tanin memiliki aktivitas antibakteri untuk kedua bakteri uji berpengaruh sangat nyata $(\mathrm{p}<0,01)$. Sehingga dapat diduga ekstrak daun belimbing juga akan bersifat antibakteri terhadap $P$. acnes yang merupakan bakteri gram positif penyebab utama jerawat.

Untuk menguji kebenaran adanya kandungan zat antibakteri pada daun belimbing wuluh, peneliti sudah melakukan penelitian pendahuluan ,pada konsentrasi 75 
Quagga: Jurnal Pendidikan dan Biologi

Volume 10, Nomor 1, Januari 2018

$\mathrm{mgml}^{-1}$ tidak terdapat zona hambat, sehingga

dapat diduga KHM pertumbuhan

Propionibacterium acne ada pada konsentrasi 100 mgml- $^{1}$.

Berdasarkan latar belakang tersebut maka penelitian ini bertujuan untuk 1)mengetahui pengaruh perbedaan konsentrasi ekstrak daun belimbing wuluh $(A$. bilimbi $L)$ terhadap zona hambat bakteri $P$ acnes secara in-vitro; 2)mengetahui konsentrasi minimal ekstrak daun belimbing wuluh (A. bilimbi $L)$ yang dapat menghambat pertumbuhan bakteri $P$ acnes secara in-vitro.

\section{METODOLOGI PENELITIAN Rancangan Penelitian}

Penelitian ini dilaksanakan di laboratorium Biologi FKIP Universitas Galuh. Penelitian menggunakan metode eksperimen dan didesain menggunakan Rancangan Acak Lengkap (RAL). Teknik pengujian menggunakan metode sumur dengan tujuh perlakuan konsentrasi ekstrak daun belimbing wuluh dan empat kali pengulangan berdasarkan hasil penelitian pendahuluan.

\section{Variabel Penelitian}

Penelitian ini menggunakan satu variabel bebas yaitu konsentrasi ekstrak daun belimbing wuluh $(A$. bilimbi $L)$ dan satu variabel terikat yaitu zona hambat bakteri $P$. acnes.

\section{Parameter}

Parameter untuk mengukur pertumbuhan bakteri pada penelitian ini adalah ukuran diameter zona hambat yang ditunjukan dengan daerah bening, yaitu daerah yang tidak ditumbuhi bakteri dalam satuan milimeter ( $\mathrm{mm})$.

\section{Alat dan Bahan}

Bahan-bahan yang digunakan dalam penelitian ini adalah daun belimbing wuluh, Muller Hinton agar, etanol, akuades, isolat bakteri $P$. acnes, $\mathrm{NaCl}$ fisiologis $0,9 \%$, dan kapas.

Alat-alat yang digunakan dalam penelitian ini adalah erlenmeyer500 $\mathrm{ml}$, kertas saring, vacuum pump, corong, timbangan analitik oven, inkubator, alumunium foil, mikropipet dan tip $1000 \mu 1$ dan $100 \mu 1$, beaker glass 50 dan $250 \mathrm{ml}$, gelas ukur $10 \mathrm{ml}$, tabung reaksi, alat pelubang berdiameter $7 \mathrm{~mm}$, jangka sorong, cawan petri, dan pipet tetes.
p-ISSN 1907-3089, e-ISSN 2651-5869

https://journal.uniku.ac.id/index.php/quagga

\section{Cara Kerja}

Tahap persiapan

Tahap persiapan dilakukan dengan menyiapkan dan sterilisasi seluruh alat dan bahan dengan memasukan seluruh alat dan bahan ke dalam autoklaf sampai suhu $121^{\circ} \mathrm{C}$ dan tekanan $15 \mathrm{lb} / \mathrm{sq}$.

Tahap pelaksanaan

1) Membuat peremajaan bakteri di atas Muller Hinton agar yang telah padat. Bakteri diinkubasikan selama 24 jam dalam suhu $37^{\circ} \mathrm{C}$.

2) Daun belimbing wuluh dipotong kecilkecil menggunakan alat pemotong dengan ukuran $\pm 1 \mathrm{~cm}$, kemudian dioven dengan suhu $70^{\circ} \mathrm{C}$ selama $1 \times 24$ jam sampai kering patah, diblender, dan kemudian ditimbang. Selanjutnya dimaserasi selama 1x24 jam dengan menggunakan etanol. Untuk membuat konsentrasi $250 \mathrm{mg} / \mathrm{ml}$ sebanyak $100 \mathrm{ml}$ maka serbuk daun yang ditimbang adalah sebanyak 25 gram kemudiaan ditambahkan larutan etanol : air (7:3) sebanyak $100 \mathrm{ml}$.

3) Ekstrak induk dengan konsentrasi 250 mgml $^{-1}$ diencerkan dengan aquadest menjadi berbagai konsentrasi yang ditentukan. Ekstrak hasil pengenceran diuapkan pada suhu $\pm 40^{\circ} \mathrm{C}$, sampai tidak tercium lagi bau etanol. Kemudian disterilisasi dalam autoklaf pada suhu $121^{\circ} \mathrm{C}$ dan tekanan $15 \mathrm{lb} / \mathrm{sq}$.

4) Konsentrasi ekstrak daun belimbing wuluh yang digunakan adalah $75 \mathrm{mgml}^{-1}$, $100 \mathrm{mgml}^{-1}, 125 \mathrm{mgml}^{-1}, 150 \mathrm{mgml}^{-1}, 175$ $\mathrm{mgml}^{-1}, 200 \mathrm{mgml}^{-1}$, dan $225 \mathrm{mgml}^{-1}$. Konsentrasi dari setiap ekstrak daun belimbing wuluh diujikan kepada bakteri uji. Uji antibakteri yang digunakan yaitu dengan menggunakan metode cup platdimana dibuat sumur pada media agar yang telah ditanami dengan mikroorganisma dan pada sumur tersebut diberi ekstrak yang akan di uji. Bahan uji diinkubasi pada suhu $37^{\circ} \mathrm{C}$ selama 24 jam di dalam inkubator. Setelah diinkubasi selama 24 jam zona hambat diamati dengan cara mengukur daerah bening (diameter zona hambat) disekitar lubang sumur dengan menggunakan jangka sorong dengan satuan milimeter. 
Quagga: Jurnal Pendidikan dan Biologi

Volume 10, Nomor 1, Januari 2018

\section{Metode Analisis Data}

Data uji daya antibakteri yang diperoleh, dianalisis menggunakan analisis ragam (ANOVA) pada tingkat kepercayaan 99\%. Setelah terdapat perbedaan yang nyata, dilanjutkan dengan uji jarak ganda Duncan (Duncan's New Multiple Range Test) pada tingkat kepercayaan yang sama (Gomez, 1995).

\section{HASIL DAN PEMBAHASAN}

Pengukuran zona hambat pada diameter daerah bening dilakukan setelah inkubasi terhadap bakteri selama 24 jam. Data Hasil pengukuran zona hambat setiap perlakuan dapat dilihat pada Tabel 1 .

Perlakuan yang menghasilkan jumlah diameter zona hambat terbesar adalah perlakuan konsentrasi $225 \mathrm{mg} \mathrm{ml}^{-1}$ dengan rata-rata diameter $12,52 \mathrm{~mm}$, sedangkan perlakuan yang menunjukan jumlah diameter zona hambat terkecil adalah perlakuan
p-ISSN 1907-3089, e-ISSN 2651-5869

https://journal.uniku.ac.id/index.php/quagga

konsentrasi $100 \mathrm{mg} \mathrm{ml}^{-1}$ dengan rata-rata diameter 7,56 $\mathrm{mm}$. Diameter yang dihasilkan oleh perlakuan konsentrasi $75 \mathrm{mg} \mathrm{ml}^{-1}$ adalah rata-rata diameter $7,00 \mathrm{~mm}$, tetapi diameter tersebut sama sekali tidak menunjukan zona hambat karena sumur yang diisi ekstrak daun belimbing wuluh dibuat dengan menggunakan alat pelubang yang berdiameter $7 \mathrm{~mm}$.

Terdapat kecenderungan bahwa konsentrasi ekstrak daun belimbing wuluh yang berbeda memberi pengaruh terhadap diameter zona hambat pertumbuhan bakteri $P$. acnes yang terbentuk, semakin tinggi konsentrasi ekstrak daun belimbing wuluh semakin besar pula diameter zona hambat terhadap pertumbuhan bakteri $P$. acnes yang terbentuk. Untuk membuktikan pengaruh perbedaan dari setiap konsentrasi tersebut maka selanjutnya dilakukan uji statistik dengan menggunakan Uji Analisis Varians Satu Faktor.

Tabel 1. Rata-rata Diameter Zona Hambat

\begin{tabular}{|c|c|c|c|c|c|c|}
\hline \multirow{3}{*}{ Perlakuan } & \multirow{2}{*}{\multicolumn{4}{|c|}{$\begin{array}{c}\text { Diameter zona hambat (mm) } \\
\text { Ulangan }\end{array}$}} & \multirow{3}{*}{$\begin{array}{l}\text { Jumlah } \\
\text { Perlakuan } \\
\text { (T) }\end{array}$} & \multirow{3}{*}{$\begin{array}{c}\text { Rataan } \\
\text { perlakuan }\end{array}$} \\
\hline & & & & & & \\
\hline & 1 & 2 & 3 & 4 & & \\
\hline Konsentrasi $10 \mathrm{mg} \mathrm{ml}^{-1}$ & 7,00 & 7,00 & 7,00 & 7,00 & 28,00 & 7,00 \\
\hline Konsentrasi $25 \mathrm{mg} \mathrm{ml}^{-1}$ & 7,75 & 7,72 & 7,50 & 7,26 & 30,23 & 7,56 \\
\hline Konsentrasi $50 \mathrm{mg} \mathrm{ml}^{-1}$ & 8,68 & 8,06 & 8,37 & 8,82 & 33,93 & 8,48 \\
\hline Konsentrasi $75 \mathrm{mg} \mathrm{ml}^{-1}$ & 9,76 & 9,84 & 10,01 & 9,90 & 39,51 & 9,88 \\
\hline Konsentrasi $100 \mathrm{mg} \mathrm{ml}^{-1}$ & 10,52 & 11,08 & 10,57 & 11,03 & 43,20 & 10,80 \\
\hline Konsentrasi $125 \mathrm{mg} \mathrm{ml}^{-1}$ & 11,58 & 11,82 & 11,62 & 12,03 & 47,05 & 11,79 \\
\hline Konsentrasi $150 \mathrm{mg} \mathrm{ml}^{-1}$ & 12,18 & 12,90 & 12,75 & 12,24 & 50,07 & 12,52 \\
\hline Jumlah Umum (G) & & & & & 271,99 & \\
\hline Rataan Umum & & & & & & 9,71 \\
\hline
\end{tabular}

Adapun ringkasan hasil analisis sidik ragam dapat disajikan pada Tabel 2 berikut.

Tabel 2. Ringkasan Analisis Sidik Ragam

\begin{tabular}{|c|c|c|c|c|c|c|}
\hline Sumber Keragaman & Derajat & \multirow{2}{*}{$\begin{array}{c}\text { Jumlah } \\
\text { Bebas }\end{array}$} & $\begin{array}{c}\text { Kuadrat } \\
\text { Kuadrat }\end{array}$ & $\begin{array}{c}\text { Tengah } \\
\text { F }\end{array}$ & & \multicolumn{2}{|c|}{$\mathbf{F}_{\text {tabel }}$} \\
& 6 & 107,18 & 17,86 & & $5 \%$ & $\mathbf{1 \%}$ \\
\hline Perlakuan & 21 & 1,31 & 0,06 & $285,28 * *$ & 2,57 & 3,81 \\
\hline Umum & 27 & 108,49 & & & & \\
\hline
\end{tabular}

Dari hasil analisis di atas terlihat bahwa nilai $\mathrm{F}_{\text {hitung }} 285,28$ lebih besar dari nilai $\mathrm{F}_{\text {tabel }}$ $(\alpha=1 \%) 3,81$ maka perlakuan berbeda sangat signifikan (**). Berdasarkan hasil tersebut konsentrasi ekstrak daun belimbing wuluh yang berbeda berpengaruh sangat nyata terhadap diameter zona hambat pertumbuhan bakteri $P$. acnes yang terbentuk secara invitro.

Selanjutnya untuk mencari perbedaan antar perlakuan dilakukan analisis beda ratarata dengan menggunakan Uji Jarak Berganda Duncan. Hasil ringkasan perbandingan antar perlakuan disajikan dalam tabel 3 . 
Quagga: Jurnal Pendidikan dan Biologi Volume 10, Nomor 1, Januari 2018

Tabel 3. Hasil Perbandingan Uji Duncan Pengukuran Zona Hambat Bakteri P. acnes dari Pengaruh Berbagai Konsentrasi Ekstrak Daun Belimbing wuluh

\begin{tabular}{|l|c|}
\hline \multicolumn{1}{|c|}{ Perlakuan } & $\begin{array}{c}\text { Rataan Diameter } \\
\text { Zona Hambat } \\
(\mathbf{m m})\end{array}$ \\
\hline Konsentrasi $75 \mathrm{mg} \mathrm{ml}^{-1}$ & $7,00 \mathrm{a}^{*}$ \\
\hline Konsentrasi $100 \mathrm{mg} \mathrm{ml}^{-1}$ & $7,56 \mathrm{~b}$ \\
\hline Konsentrasi $125 \mathrm{mg} \mathrm{ml}^{-1}$ & $8,48 \mathrm{c}$ \\
\hline Konsentrasi $150 \mathrm{mg} \mathrm{m}^{-1}$ & $9,88 \mathrm{~d}$ \\
\hline Konsentrasi $175 \mathrm{mg} \mathrm{ml}^{-1}$ & $10,80 \mathrm{e}$ \\
\hline Konsentrasi $200 \mathrm{mg} \mathrm{ml}^{-1}$ & $11,76 \mathrm{f}$ \\
\hline Konsentrasi $225 \mathrm{mg} \mathrm{ml}^{-1}$ & $12,52 \mathrm{~g}$ \\
\hline
\end{tabular}

Berdasarkan tabel angka yang diikuti huruf yang sama menunjukan tidak berbeda nyatadengan Uji Duncan pada taraf kepercayaan $(\alpha) \quad 1 \%$. Angka yang diikuti huruf yang berbeda menunjukan berbeda sangat nyatadengan Uji Duncan pada taraf kepercayaan $(\alpha) \quad 1 \%$.

Dari hasil penelitian konsentrasi minimal atau kadar hambat miminum (KHM) ekstrak daun belimbing wuluh yang dapat membentuk zona hambat pertumbuhan bakteri $P$ acnes adalah $100 \mathrm{mgml}^{-1}$. Konsentrasi tersebut dianggap sebagai konsentrasi yang paling efektiv yang dapat menghambat pertumbuhan bakteri $P$ acnes dan terlihat berbeda sangat nyata dengan perlakuan lainnya.

Berdasarkan hasil penelitian Uji Ekstrak Daun Belimbing wuluh Terhadap Zona Hambat Pertumbuhan Bakteri P.acnes secara In-Vitro, dapat terbentuk zona hambat atau daerah bening pada media agar yang tidak ditumbuhi oleh bakteri karena adanya zat antimikroba dari ekstrak daun belimbing wuluh yang diberikan sehingga secara difusi menyebar pada media agar.

Berdasarkan Analisis Sidik Ragam (Analisis Varians), diketahui bahwa konsentrasi ekstrak daun belimbing wuluh yang berbeda berpengaruh sangat nyata terhadap diameter zona hambat pertumbuhan bakteri $P$. acnes yang terbentuk secara invitro.

Analisis Uji Duncan memberikan hasil bahwa konsentrasi terendah yang dapat menghambat pertumbuhan P.acnes adalah $100 \mathrm{mgml}^{-1}$. Sedangkan perlakuan dengan
p-ISSN 1907-3089, e-ISSN 2651-5869

https://journal.uniku.ac.id/index.php/quagga

konsentrasi $75 \mathrm{mgml}^{-1}$ sama sekali tidak menunjukan zona hambat, hal ini dikarenakan zat antimikroba yang terdapat dalam ekstrak tidak mampu untuk menghambat pertumbuhan bakteri.

Berdasarkan hal tersebut dapat dinyatakan bahwa semakin tinggi konsentrasi ekstrak daun belimbing wuluh diberikan maka semakin besar pula diameter zona hambat yang ditunjukan terhadap pertumbuhan bakteri P.acnes. Hal tersebut sesuai dengan teori yang dikemukakan oleh Dwidjoseputro (2005), bahwa konsentrasi antimikroba mempengaruhi pertumbuhan mikroorganisme, semakin tinggi konsentrasi antimikroba maka semakin besar pula jumlah mikroba yang dihambat pertumbuhannya.

Pengaruh perbedaan konsentrasi antimikroba terhadap pertumbuhan mikroorganisme dibuktikan dengan penelitian yang dilakukan yaitu Uji Efektivitas Ekstrak Daun Belimbing wuluh terhadap Zona Hambat Pertumbuhan bakteri $P$ acnes secara In-vitro yang dilakukan dengan metode difusi sumur, ekstrak daun belimbing wuluh dengan berbagai konsentrasi dimasukan ke dalam lubang sumur pada cawan petri dan kemudian ekstrak tersebut akan berdifusi ke dalam biakan bakteri $P$ acnes pada media agar.

Ekstrak daun belimbing wuluh dengan berbagai konsentrasi yang berbeda tersebut mengandung zat antimikroba yang berbeda pula dan dapat membunuh atau menghambat pertumbuhan $P$ acnes sehingga menimbulkan zona hambat yang berupa daerah bening disekitar sumur. Diameter zona bening yang terbentuk menunjukan bahwa media agar tidak lagi ditumbuhi oleh bakteri $P$. acnes.

Perbedaan konsentrasi ekstrak yang digunakan menyebabkan zona bening yang menunjukan daya hambatnya yang ditunjukan juga berbeda-beda. Semakin tinggi konsentrasi ekstrak daun belimbing wuluh berarti semakin pekat larutan tersebut dan semakin banyak pula jumlah zat-zat antimikroba yang terkandung di dalamnya. Bila jumlah zat antimikroba semakin besar maka semakin besar pula bakteri P.acnes yang dirusak baik itu struktur tubuh maupun sistem metabolismenya, sehingga bakteri yang terkena oleh zat antimikroba tersebut akan mati atau dihambat pertumbuhannya. 
Quagga: Jurnal Pendidikan dan Biologi Volume 10, Nomor 1, Januari 2018

Hal ini sesuai dengan pendapat Kamilah (2010) bahwa kandungan yang terdapat dalam daun belimbing wuluh yang bekerja sebagai antibakteri adalah Tanin dan Flavonoid. Senyawa Flavonoid merupakan salah satu antibakteri yang bekerja dengan mengganggu fungsi membran sitoplasma. Flavonoid mampu membentuk senyawa kompleks dengan protein ekstraseluler dan terlarut dengan dinding sel. Zat antimikroba yang menghalangi fungsi penting membran dapat mengakibatkan kematian sel atau ketidakmampuan untuk tumbuh dan berkembang.

Membran bakteri bersifat semipermeabel yang mengatur substansi keluar masuk sel. Kerusakan membran memungkinkan ion organik penting, nukleotida, koenzim, dan asam amino merembes keluar sel. Kerusakan membran plasma ini menghambat atau merusak kemampuannya bertindak sebagai penghalang osmosis dan mencegah berlangsungnya biosintesis, sedangkan senyawa Tanin mampu menghambat pertumbuhan mikroorganisme dengan kemampuanya menginaktivasi adhesin mikroba, enzim dan protein transpor cell envelove.

Flavonoid dan Tanin merupakan senyawa aktif dalam tanaman yang berkhasiat sebagai obat yang dapat menyembuhkan penyakit infeksi. Dalam penentuan dosis obat kedokteran perlu dilakukan uji secara in-vitro sebelum diterapakan secara in-vivo dan diperlukan Konsentrasi Hambat minimum (KHM) atau Minimal Inhibitor Concentration (MIC) dari antimikroba. Hal ini sesuai dengan pendapat yang dikemukakan oleh Jawetz et.al. (2001). KHM dianggap efektif digunakan karena penggunaan zat antimikroba dalam konsentrasi yang tinggi dikhawatirkan akan menimbulkan efek samping atau fisiologis bagi tubuh manusia.

Berdasarkan hasil uji pendahuluan yang dilakukan konsentrasi yang terkecil yang dapat menghambat pertumbuhan P.acnes adalah konsentrasi ekstrak $100 \mathrm{mgml}^{-1}$ hal ini ditunjukan dengan adanya zona bening yang terbentuk. Hasil uji pendahuluan kemudian menjadi dasar uji lanjutan dan dari hasil yang pengamatan terbukti bahwa konsentrasi ekstrak minimal yang efektif digunakan adalah $100 \mathrm{mgml}^{-1}$. Namun demikian masih
p-ISSN 1907-3089, e-ISSN 2651-5869

https://journal.uniku.ac.id/index.php/quagga

perlu dilakukan uji lanjut secara in-vivo pengaruh perbedaan konsentrasi ekstrak daun belimbing wuluh sebelum diaplikasikan sebagai obat jerawat atau pun sebagai masker alami untuk mengetahui efek fisiologis secara langsung bagi tubuh manusia.

\section{SIMPULAN}

Perbedaan konsentrasi ekstrak daun belimbing wuluh(A. bilimbi $L)$ berpengaruh sangat nyata terhadap zona hambat pertumbuhan bakteri P.acnes secara in-vitro pada taraf nyata $(\alpha) \quad 1 \%$. Kadar hambat minimum dari ekstrak daun daun belimbing wuluh $(A$. bilimbi $L)$ yang dapat menghambat pertumbuhan bakteri P.acnes secara in-vitro adalah $100 \mathrm{mgml}^{-1}$.

\section{REFERENSI}

Arland. 2007. Propionibacterium acnes. Tersedia: http: //www.ebi.ac.uk/2can/genomes/bacte ria/Propionibacterium acnes. Akses online 3 November 2016.

Azifitria, et.al . 2010. Aktivitas Antibakteri Ekstrak Etanolik Daun Dan Umbi Crinum asiatum L, Terhadap Bakteri Penyebab Jerawat. Cibinong: Puslit Biologi LIPI.

Brown, R.G. 2009. Lectures Notes Dermatologi, Jakarta: Erlangga

Cappuccino,J \& Natalie Sherman. 1982. Microbiology : A Laboratory Manual. Suffern ,New York

Faharani, B.G.R. 2009. Uji Aktivitas Antibakteri Daun Belimbing wuluh terhadap Bakteri aureus dan E. Coli secara Bioautografi, Yogyakarta

Gomes, KA.1995. Statistika Untuk Penelitian Pertanian. Alih Bahasa Endang Sjamsudin, dkk. Edisi 2, Universitas Indonesi, Jakarta.

Jawetz, et.al. 2001. Mikrobiologi kedokteran, Jakarta:Salemba Medika

Kamilah, E. 2010. Dibalik Mukzizat Tanaman Belimbing wuluh Sebagai Pengawet Alami. Tersedia : http: I/ elokkamilah. wordpress.com diakses tanggal 15 Oktober 2016.

Pelczart, M.J dan Chan E.C.S. 1986. DasarDasar Mikrobiologi. Jilid 1 dan 2. Terjemahan Hadioetomo, R.S.dkk, Jakarta: Universitas Indonesia Press 
Quagga: Jurnal Pendidikan dan Biologi

Volume 10, Nomor 1, Januari 2018

Rismunandar. 1981. Tanaman Belimbing wuluh yang Serba Guna, Bandung: PT Sinar Baru.

Robinson, T. 1995. Kandungan Organik Tumbuhan Tinggi. Bandung : ITB

Sarastani, D. Dedi Fardiaz, Anton Apriyantono, dkk. 2002. Senyawa Antimikroba dari Tanaman.http://indobic.biotrop.org/b erita detail.php?id berita $=124$.

Volk and Wheeler. 1988. Mikrobiologi Dasar, Edisi kelima, Jilid 1 dan, Jakarta: Erlangga.
p-ISSN 1907-3089, e-ISSN 2651-5869

https://journal.uniku.ac.id/index.php/quagga 